\title{
Impact of GDM on Athlete's Immunocompetence
}

\author{
Dong Cong-Min ${ }^{*}$
}

\section{P.E. Department, Zhengzhou Institute of Aeronautical Industry Management, China}

\begin{abstract}
Purpose: Explore the impact of GDM on athlete's immunocompetence. Method: Analyze the peripheral white blood cell variation within the body of 50 football players and students from the specialized class before and after they take GDM, as well as E rosette test of $\mathrm{T}$ cell and IgG, IgA and IgM content in serum. Result: The result shows that the E rosette rate of formation of $\mathrm{T}$ lymphocyte within the body of these football players has not changed obviously after longterm sports, but the IgG content in serum is less than that of the students from specialized class $(\mathrm{P}<0.05)$; after taking GDM for four weeks, the IgM in these students' serum increases greatly $(\mathrm{P}<0.05)$; and the white blood cell count in peripheral blood also increases greatly $(\mathrm{P}<0.05)$. Conclusion: This result indicates that athlete's immunocompetence will be affected after long-term sports, and improved to a certain extent after taking GDM.
\end{abstract}

Keywords: Athlete, GDM, immunocompetence.

\section{INTRODUCTION}

GDM (Gong' a Drinking Material) refers to the natural drink that is mixed by many kinds of juices based on a certain proportion. The relevant studies indicate that GDM, a superior drink, can improve the deformability of red blood cell within the body of athletes and general students, multiply the hemoglobin content within the body of athletes, and reduce the urine protein content within the body of athletes after plenty of exercise. This paper selects the students from the special football player class in the institute of physical education of one city as the object of study, so as to analyze their immunocompetence in training and competition before and after taking GDM, as well as explore the impact of longterm exercise training and different intensity of training on athlete's immunocompetence. The details are summarized as below.

\section{OBJECT AND METHOD}

\subsection{General Object}

50 football players and students from the specialized class in the institute of physical education of one city are selected as the object of study, 25 football players are assigned to Group A, and the other 25 students from special football class are assigned to Group B. 50 students are all in good health and have not suffered from infectious diseases within four weeks. The physical condition of the two groups is shown as in Table $\mathbf{1}$.

\subsection{Drink and Drinking Method}

The drink includes placebo and GDM, 50\% GDM is mixed with single-flavor fresh orange juice. The two drinks are packed in glass bottle, $250 \mathrm{ml}$ for each. And both are

*Address correspondence to this author at the P.E. Department, Zhengzhou Institute of Aeronautical Industry Management, China;

Tel: 13533435919; E-mail: 2745415878@qq.com sterilized by high temperature [1]. After the test on relevant parts, the two drinks do not contain the drug for athletes forbidden by the International Olympic Committee. The two drinks have the same package and color. The two groups begin to drink the drinks after index inspection. 50\% GDM is for Group A, two bottles per day (in the morning and evening respectively). Placebo is for Group B, with the same dosage and taking method as Group A. The two drinks are delivered by specially-assigned persons, and the distributors and testees do not understand the drink well. After the testees drink the drink, they will not directly participate in the test and operation in experiment [2].

\subsection{Test Index and Instrument}

When detecting the immunocompetence of testees, pick $3 \mathrm{ml}$ venous blood from their median cubital vein after they have a rest in a quiet laboratory for 20 minutes, and then conduct heparin anticoagulant treatment for blood. Later, conduct the test on the rosette rate of formation of $\mathrm{T}$ lymphocyte and sheep red blood cell (hereinafter referred to as $\mathrm{E}$ rosette test) and measure $\operatorname{IgA}, \operatorname{IgG}$ and $\operatorname{IgM}$ contents in testee's serum. Collect blood from the third fingertip of testee's left hand to make blood smear and determine the count and classification of white blood cell [3]. E rosette test of T cell adopts total magnitude method for determination; serum immunoglobulin is determined by the immunochemistry automatic analyzer manufactured in America. Before and after drinking the drinks for four weeks, the testees should receive the above test projects. In order to avoid the potential impact of circadian rhythm on some physiology and biochemistry indexes, each testee should take the tests at the same time within one day.

\subsection{Statistical Treatment}

In terms of mathematical statistics, compare the individual data and group data and then conduct $t$ test. $\mathrm{P}<0.05$ means that it is of the statistical significance. 
Table 1. Physical condition of group $A$ and group $B(\overline{\mathrm{X}} \pm \mathrm{SD})$.

\begin{tabular}{|c|c|c|c|c|c|}
\hline Group & Number of Testees & Height (cm) & Weight (kg) & Age (Years) & Training Time (year) \\
\hline \hline A & 25 & $178.1 \pm 5.6$ & $72.1 \pm 5.2$ & $23.5 \pm 1.8$ & $7-13$ \\
\hline B & 25 & $174.2 \pm 4.6$ & $64.8 \pm 4.7$ & $20.4 \pm 0.9$ & $1-7$ \\
\hline
\end{tabular}

Table 2. Immunocompetence Comparison before Group A and Group B Drink the Drinks $(\overline{\mathrm{X}} \pm \mathrm{SD})$.

\begin{tabular}{|c|c|c|c|c|c|}
\hline Group & Number of Testees & $\begin{array}{c}\text { E Rosette Rate of } \\
\text { Formation (\%) }\end{array}$ & IgA (g/L) & IgG (g/L) & IgM (g/L) \\
\hline \hline Normal value & & $68.0 \pm 9.8$ & $2.00 \pm 0.51$ & $12.00 \pm 2.61$ & $1.10 \pm 0.30$ \\
\hline Group A & 25 & $68.9 \pm 3.2$ & $2.97 \pm 0.65$ & $1.85 \pm 1.83$ & $1.09 \pm 0.36$ \\
\hline Group B & 25 & $68.2 \pm 6.4$ & $10.35 \pm 2.16$ & $1.35 \pm 0.38$ \\
\hline
\end{tabular}

Table 3. Comparison of IgG content in serum after the testees from group A and group B drink the drinks for four weeks ( $\overline{\mathrm{X}} \pm \mathrm{SD})$.

\begin{tabular}{|c|c|c|c|}
\hline Group & Number of Testees & Group A & Group B \\
\hline \hline Before drinking the drink & 25 & $7.85 \pm 1.83$ & $10.35 \pm 2.16$ \\
\hline After drink the drink & 25 & $9.15 \pm 2.13$ & $10.15 \pm 2.26$ \\
\hline $\mathrm{t}$ & - & 6.89 & -0.34 \\
\hline $\mathrm{P}$ & - & $\mathrm{P}<0.05$ & $\mathrm{P}>0.05$ \\
\hline
\end{tabular}

Table 4. Change in the total number of white blood cells before and after group A and group B drink the drinks for four weeks $(\overline{\mathrm{X}} \pm \mathbf{S D})$.

\begin{tabular}{|c|c|c|c|}
\hline Group & Number of Testees & Group A & Group B \\
\hline \hline Before drinking the drink & 25 & $5172.2 \pm 1528.3$ & $5320.4 \pm 1598.2$ \\
\hline After drinking the drink & 25 & $5733.2 \pm 721.5$ & $4921.7 \pm 631.2$ \\
\hline $\mathrm{t}$ & - & 6.74 & -0.35 \\
\hline $\mathrm{P}$ & - & $\mathrm{P}<0.05$ & $\mathrm{P}>0.05$ \\
\hline
\end{tabular}

\section{RESULT}

\subsection{Immune Function Comparison Of Two Groups Be- fore Drinking The Drinks}

The determination result of $E$ rosette test and serum immunoglobulin content before the two groups drink the drinks is shown in Table 2.

3.3. Impact of GDM on The Total Number of Peripheral It can be seen from Table 2 that before the testees from Group A and Group B drink the drinks, there is no bigger difference in their E rosette rates of formation, which is almost the same with the normal value. Therefore, the serum immunoglobulin ( $\mathrm{IgG}$ ) content of Group $\mathrm{A}$ is less than that of Group B obviously and the difference is of distinct statis- tical significance. The immunocompetence of the two groups is in the normal range.

\subsection{Impact of GDM On E Rosette Test And Immuno- globulin Content}

After the testees from the two groups drink the drinks for two weeks, their $\mathrm{E}$ rosette rates of formation have not changed significantly. However, the IgG content in serum of Group A increases greatly and the difference is of distinct statistical significance when compared with the content before the drinks. The IgG content in serum of Group B has not changed a lot, and the details are shown as in Table 3. Before and after the testees from the two groups drink the drinks, their IgA and IgM in serum have not changed obviously. 


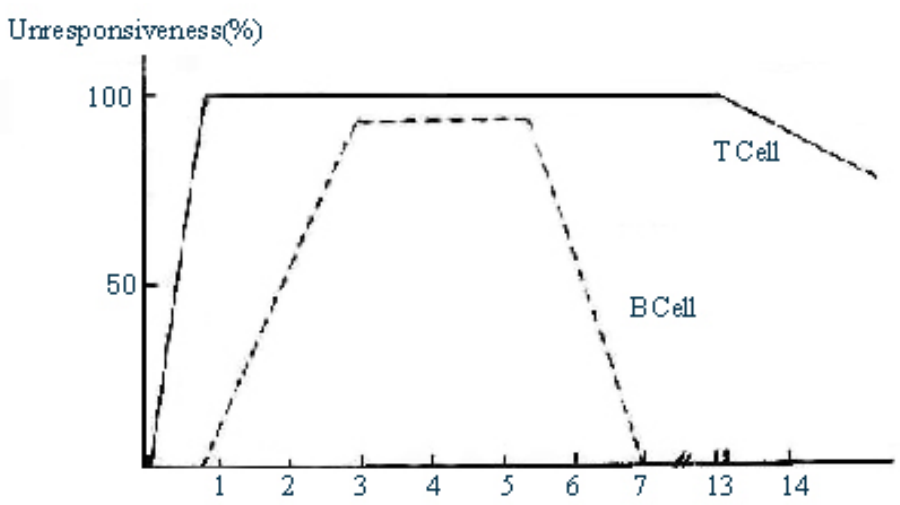

Fig. (1). Reaction of T cell and B cell tolerance.

\subsection{Impact of GDM on The Total Number of Peripheral White Blood Cell}

See Table 4 for the change in the total number of peripheral white blood cell before and after the two groups drink the drinks.

After Group B takes the placebo, the total number of their white blood cell decreases slightly. Before taking the placebo, 15 of them have 5,000 white blood cells/ mm3. After taking the placebo, 8 of them have less than 5,000 white blood cells. After Group A takes GDM for four weeks, their total number of white blood cells increases greatly. Before taking GDM, five of them have less than 5,000 white blood cells/ mm3; after taking GDM, only two of them have less than 5,000 white blood cells/ $\mathrm{mm} 3$. Before and after drinking the drinks, the two groups have less than 10,000 white blood cells/ $\mathrm{mm} 3$ in total.

\section{ANALYSIS AND DISCUSSION}

It is found in relevant studies that intensive exercise is able to change human body's immune function and there is less analysis on the impact of long-term exercise on athlete's immunocompetence. This study selects long-term athletes and specialized sport students for analysis and it is discovered that after long-term exercise, the E rosette rate of formation of T cell in football player's body is within the normal range, but the total number of peripheral white blood cell is at the lower level of normal range [4]. The exercise training of football players from Group A is more intensive, with longer training time. Therefore, the IgG content in their serum is obviously less than that of Group B. Compared to the normal value, the contents in Group A and Group B are distinctly less than that of the normal. During training and competition process, the energy for football player's muscle contraction is provided in an aerobic way and glycolysis will also supply energy to varying degrees [5]. Although the E rosette rate of formation of $\mathrm{T}$ cell within the body of testees has not declined, the IgG content in serum reduces, thus resulting in the decline of athlete's immuncompetence. This circumstance will lead to the susceptibility of disease, cause serious harm to the health level of athletes and lower their athletic ability. The reaction of $\mathrm{T}$ cell and $\mathrm{B}$ cell tolerance in the body of testees is shown as in Fig. (1).

Football players are affected by training and competition and live with high-volume training for a long time. Although they have the same serum slymphocyte and E rosette rate of formation in resting state as the normal, the IgG content in their serum is obviously lower. The study shows that football players from Group A have less IgG than that of Group B and 15 of them have white blood cells in peripheral blood less than the normal level, which indicates that the immunocompetence of athletes will be affected by long-term intensive exercise training. This phenomenon should be paid attention to by coaches, athletes and doctors and reasonable manners should be adopted for relief [6].

After the testees drink the drink of GDM for four weeks, their $\mathrm{E}$ rosette rate of formation of $\mathrm{T}$ lymphocyte increases, but is still in the normal range. The IgG content in serum increases obviously, gradually close to the normal level. The number of testees whose white blood cell content is within the normal range increases distinctly, which signifies that GDM plays a role in improving and stabilizing athlete's immune mechanism.

Both the serum immunoglobulin content and the number of peripheral white blood cell can be at a relatively stable state after neuroendocrine regulation. Long-term exercise and training will affect the immunocompetence and lower the immune level. Athlete's immune function can be stabilized and return to normal gradually by drinking the superior drink of GDM. Further study needs to be conducted to understand whether GDM contains some regulation substances that can stabilize the immune function or the substance that can facilitate the synthesis of some regulation substances. Besides, further study is needed to know whether long-term training may affect the variation of $T$ cell subset as well as the approach for GDM to stabilize and improve athlete's immunocompetence [7].

\section{CONCLUSION}

Long-term exercise and training exert no significant impact on the $\mathrm{E}$ rosette rate of formation of $\mathrm{T}$ cell, but the $\mathrm{IgG}$ content in serum is obviously less than the normal value. The IgG content in serum of Group A is obviously lower than that of specialized football class. It indicates that long-term exercise and training may affect football player's immune function; and long-term exercise and training may result in less total peripheral white blood cells of football players and the athletes who have less white blood cells than the normal value take a higher proportion. After the athletes take GDM for four weeks, their IgG content in serum increases greatly, 
the average value of total peripheral white blood cells rises, and the proportion that total white blood cells are not within the range of normal value, which signifies that GDM plays a significant role in improving and stabilizing football player's immune function.

\section{CONFLICT OF INTEREST}

The author confirms that this article content has no conflict of interest.

\section{ACKNOWLEDGEMENTS}

Declared none.

\section{REFERENCES}

[1] J. Zhou, "Impact of HiHiLo and LoHi Simulated Hypoxia Exercise on Basketball Player's Immuno competence," Journal of Beijing
Sport University, vol. 32, no. 8, pp. 68-69, 2009.

[2] H. Zhang, "Mechanism Analysis on Traditional Chinese Medicine Improving Athlete's Immuno competence," Modern Integrated Traditional Chinese and Western Medicine, vol. 19, no. 33, pp. 4363-4364, 2010

[3] G. Wang, "Study on Monitoring Male Rower's Body Function Status in Long-time Sub-plateau Training and Special Training Method," Shanghai University of Sport, no. 10, pp. 1-121, 2013.

[4] J. Wang, "Evaluation on the Immune Function Impact of High-level Basketball Players in Colleges and Universities," Fujian Sports Science and Technology, vol. 30, no. 6, pp. 27-28, 2011.

[5] B. Gou, B. Wang, L. Pan, B. Gao, Y. Guo, Y. Wang, B. Zhang, S. $\mathrm{Lu}$, and G. Wang, "Monitoring of Training Function Status of Chinese Sanda Team before Doha Asian Games with Biochemical Index, "Journal of Capital Institute of Physical Education, vol. 22, no. 3, pp. 60-61, 2010.

[6] Y. Fang, Y. Pei, Z. Li, X. Fan, Z. Li, and L. Jing, "Impact of Intensive Training on Speed Skater's Immune System," China Winter Sports, vol. 32, no. 2, pp. 57-61, 2010.

(C) Dong Cong-min; Licensee Bentham Open.

This is an open access article licensed under the terms of the (https://creativecommons.org/licenses/by/4.0/legalcode), which permits unrestricted, noncommercial use, distribution and reproduction in any medium, provided the work is properly cited. 